\title{
Manufacturing role in simple product development at a multiproject environment
}

\author{
Ana Maria Gati, Paulo Tromboni \\ University of São Paulo \\ e-mails: anagati@uol.com.br; trombone@usp.br
}

\begin{abstract}
This article concerns the role of manufacturing in the innovation process within a company environment characterized by simple products and multi-project development. The objective of this research was to understand the manufacturing management practices in product and process development. Three Brazilian companies from different business sectors - cosmetics, candies and shoes - were studied. Derivative projects are the main business of the innovation process in these companies. However, there are also some platform and breakthrough projects in each company at every period. Results showed that manufacturing plays an important role in the innovation process at strategic and implementation levels. One important finding was that co-location of research and development R\&D, marketing, and manufacturing units and staff may substitute co-location of project teams; another finding was that manufacturing may have a leading role in project definition, selection and management, whenever it is a dominant function at the company, defining the common language concerning products. When production is not the leading function in company parlance, R\&D may take the role of translator, facilitating the required communication between manufacturing and other areas in the innovation process.
\end{abstract}

Keywords: operations and innovation, project portfolio, manufacturing and new products.

\section{Introduction}

Product and process development have sustained high competitive advantage in the current business environment, when compared with existent products and processes.

However, to ensure fast speed in development demands a fast and continuous process of product creation and production. When speed is required, manufacturing have an active role in the product concept development and project implementation. The benefit lies on introducing the product in the market as soon as possible, before someone else is able to copy it. Many companies with a frequent innovation profile have considerable amount of their annual financial revenue, total sales, depending upon new products.

Manufacturing effective involvement in the NPD (New Product and Process Development) processnot always happens in the way or at least at the intensity which would be ideally recommended. In fact, design phase potentially impacts downstream manufacturing and has been postulated to affect both the cost and leadtime as well (BAJAJ; KELKRE; SIRINIVASAN, 2004). For this reason, earlier participation in the NPD process should have a positive impact.

To understand the practices of manufacturing participation in NPD process with simple products and multiproject environment is the main focus of this research.
Innovative companies and short life cycle products are a reality in this environment.

This research's subject matter is simple products (CLARK; FUJIMOTO, 1991); products with few interaction with consumers, as packed products (food, cosmetics and households cleaning products), as well as clothes and shoes.

Companies launching many products in a year face a multiproject environment (ASH; SMITH-DANIELS, 1999), which requires high alignment of people and departments involved in the NPD process with the factories, to ensure effectiveness of the project implementation. NPD process, mainly during the initial designing phases potentially impacts downstream manufacturing and has been postulated (BAJAJ; KELKRE; SIRINIVASAN, 2004) to affect both the cost and project lead lime. In this multiproject environment, in which short-life products are normally in majority, excellence on NPD process execution is very important for business success.

In a multiproject environment, the need is very intensive for human resources with great experience in manufacturing, and this hinders their effective participation in several projects. This competition for scarce well-qualified resources (CLARK; WHEELWRIGHT, 1993) may delay projects execution, besides downgrading their quality. An example of experienced resources are the gatekeeper's 
role, people who who manage the information exchange between the organization'soutside and inside regardless of job description, aconcept initially described in the 70's (ALLEN, 1997) and reinforced in today's internet globalized reality (ETTLIE; EISENBACH, 2007).

The focus of this research is the innovative company, that is, the company with frequent product and process development projects, followed by product launching and commercialization. Onlytangible products sold to the final consumer are considered in this analysis. The NPD project portfolio of these companies may present highly innovative products, however many of these innovations may be incremental.

As per today reality (COOPER; SCOTT; KLEINSCHMIDT, 2004) several issues of new projects prioritization and proper allocation of resources as well as resources deficiencyacross the many business and projects makes difficult to have dedicated focused resources in one single project. The human resources have other responsabilities like to fix and repair or are also involved in other projects. Quite a different situationfrom the one described by Clark and Wheelwright (1993), whom recommend dedicated and co-localizedresources (teams physically located at the same place) for NPD processes focused in complex products, breakthrough or plataform, in the automobile industry.

Another important topic in the competition between the projects and the daily operational routine of experienced human resources is the implementation of the DFM methodology. Design For Manufacturing (CLARK; WHEELWRIGHT, 1993), involves: (i) to establish the current process envelop, (ii) to identify important connections between design alternatives and the development of the manufacturing system; and (iii) to establish the key dimensions of the product architecture and its impact in the manufacturing system. In order to thoroughly use the DFM methodology, the process needs to be interactive, that is, product and process specialists need to perform an integrated work in product development as well as in the manufacturing process.

Among the several in the literature, Youssef (1994) presents some definitions of DFM: Simultaneous Engineering - SE, Engineering for Excellence - EFE, Concurrent Product and Process Development - CPPD, Design for Production - DFP, Design for Assembling - DFA and Productivity Engineering - PE.

Although it facilitates the productive process, DFM in the NPD process could be a challenge in a multi-project environment, as time for analysis of each project is limited and requires excellent coordination either among the human resources or among the specific management practices.

The role of manufacturing in the innovation process can be evidenced at two levels: the strategic and the NPD process. At the strategic level, through the new product and process projects portfolio management. At the NPD process level, through discussing the engagement of manufacturing in each project.

In this research both levels have beenaddressed, strategic and NPD process, in a multiproject environment. The following questionshave thus been identified our research focus:

- Why does manufacturing participate in the development process?;

- How this participation works?; and

- Which practices are used to guarantee and turn feasible this participation?

\section{Theorethical fundation}

\subsection{Types of projects}

Clark and Wheelwright (1993) suggest there are four types of new product and process projects defined according to the newness degree: Advanced Development Projects, Breakthrough Projects, Platform and Derivatives Projects. The authors add a fifth type of Commercial Partnerships and Alliances, which can be created to turn feasible or profitable any of the former types.

Considering the projects addressed in this research, that is, simple products with low technical uncertainty, the Clark and Wheelwright (1993) classification of derivative projects is appropriate for our analysis. As most of the products of this research are derivative, it will be used a further subdivision between incremental and topological projects (SANDERSON; UZUMERI, 1995).

\subsection{NPD process steps}

The commercial product and process development involves some typical steps such as concept development, product planning, process and product engineering, pilot production and final production start up.

Table 1. NPD process steps, per Author.

\begin{tabular}{|l|c|}
\hline \multicolumn{1}{|c|}{ Author/Year } & $\begin{array}{c}\text { Number of NPD } \\
\text { process stages }\end{array}$ \\
\hline Matar and Santos (2003) & 10 \\
\hline Rama and Herbig (1996) & 8 \\
\hline Griffin, Anschetz and Castellion (1996) & 5 \\
\hline Clark and Wheelwright (1993) & 4 \\
\hline Tritle, Striven and Fusfeld (2000) & 4 \\
\hline Reid and Sanders (2005) & 4 \\
\hline Fredericks (2005) & 2 \\
\hline Olson et al. (2001) & 2 \\
\hline
\end{tabular}


According to the literature however, there is no consensus about the number of stages for the product and process development process, Table 1.

For this research, four NPD process steps are used:

- Conception (idea, definition);

- Project planning (business planning and development, activities planning, resources quantification, scheduling and team organization);

- Implementation - product development (tests, experiments, prototypes) and process development (tests, experiments, pilot and engineering, others tests); and

- Commercialization after the product launching (changes, project adjustments or improvements).

\subsection{Project porffolio}

As a priority, in terms of clear project portfolio and NPD goals, it is very important the strategic aligment with company goals in order to have successfull projects (COOPER; SCOTT; KLEINSCHMIDT, 2004).

Different reasons can generate the project portfolio in a company: competition, size of market, product safety regulations, economic regulations, product effectiveness regulation, safety process conditions, environmental perils, involved resources and financial amounts.Although the financial criterion to define project portfolio priorization is highly used (COOPER, 1994), it can not be the only one, as it may lead to a wrong project selection. Projects can be on different initial stages of evaluation and the uncertainties may sometimes be very big. For the author, there are many dimensions to evaluate a project portfolio.

At the projects portfoliophase, manufacturing needs to evaluate whether there are process changes for each NPD project, and how this will affect production. These changes can happen at different levels, turning easier the project planning process, as follows:

- Small changes in the existent product/process, tools or devices to adapt to the new product - derivative innovation;

- Production line change, which requires planning and possible acquisition of a new production line for a new product - derivative or platform product innovation; and

- New factory or new business unit, depending upon the product or technology to be applied - the innovation can be considered breakthrough for that company.

\subsection{Types of organization for the NPD project execution}

There are some essential elements in development (BROWN; EINSENHART, 1995): communication, problem solving and appropriate organization. Other authors reinforce these aspects (GRIFFIN; HAUSER, 1996), the harmony among team members is based on interpersonal relationships and cooperation

Although the utilization of multi task teams does not reduce the risk of finalfailure (GERWIN; BARROWMAN, 2002), the possibility of searching for a faster team to develop products and processes enables the organization to create multi task groups, which in general generates positive results, if adequately managed. The authors still emphasize the importance of an accurate selection of the multi task team participants, as well as to ponder whether this is the best alternative for the NPD Project in question.

Different projects require different organization proposals (OLSON; WALKER; RUEKERT, 1995) as control mechanisms. In the case of less complex development projects, the line extensions and modifications, centralized and formalized structures seem to bring the best results. Besides, the organic and participative structures are in general more expensive. Decentralized organic structures and participative coordination mechanisms are associated with better results in very innovative NPD projects, (OLSON; WALKER; RUEKER, 1995) in which the company has little experience and knowledge.

Some technological tools, such as CAD (computer aided design)/CAM (computer aided manufacturing) used by the companies, can anticipate possible manufacturing difficulties early on, at the prototype and sample stage, optimizing the products transfer from R\&D to the factory, acoording Adler (1995).

For the research in a multiproject and simple product environment, it is important to identify how project management is applied, how to optimize (in a more productive way) the scarce human resources participation in the NPD process, and how the organizational structure can be adjusted to the changes in the project portfolio composition.

The multiproject NPD process is far more susceptible to fire fighting than other environments, (REPENNING, 2001). This fire fighting happens mainly due to the difficulties of resource allocation, resulting in poor project time and cost performance.

\subsection{Manufacturing participation practices in NPD projects}

\subsubsection{NPD management practices}

Some NDP process management practices identified in the literature are listed below:

- Collaborative interface between marketing and manufacturing, (CALANTONE; DRÖGE; VICKERY, 2002; LEONARD-BARTON, 1992; OLSON et al., 2001);

- Review meetings along the NPD process and written contract before initiating the project, Adler (1995);

- Late freeze of specifications and suppliers 
involveme,job rotation between P\&D and manufacturing, registering lessons learned, Ward, Liker and Cristiano (1995)

- Open communication and facilitators to remove barriers, (COOPER; SCOTT; KLEINSCHMIDT, 2002; GRIFFEN; HAUSER, 1996;OLSON et al., 2001; HONG et al., 2005);

- Time coordination, (MATTAR, 2003; KISHMANN; ULRICH, 2001);

- Decision process, Henke et al. (1993);

- Team recognition as a tool for motivation, Cooper, Scott and Kleinschmidt (2004); and

- Team members additional roles:team members as design engineers with the role of convincing the organization about the project, Ancano and Caldwell (2007),team members to act as gatekeepers (ALLEN, 1997; ETTLIE; EISENBACH, 2007; KATZ; TUSHMAN, 1981).

Although the use of multi task teams has been very common in most companies, Olson et al. (2001) observe that cooperation between different functional areas in the NPD process is complex, as it depends on the type of the project, the functional job as well as on the moment when this cooperation is required.

Consumer goods business and multiproject environment creates a complex resource allocation challenge to NPD process execution and management, to be met by several best practices presented in the literature (GUPTA, 2005), such as avoiding to start projects too early and creating project buffers in the development and implementation phases.

Leonard-Barton (1992) defines fourcapability dimensions in a product and process development: technical systems, management systems, knowledge basis and abilities. They interact through time in the companies. Thus, the author emphasizes that, depending on the company, some areas participating in the NPD process may be more dominating or draw more attention in detriment to others, which may hinder the more effective participation of less influent or powerful areas within an organization.

Adler (1995) describes that some project control and coordination key points have been used and discussed in the literature, among which: project contract, design freeze at a certain point in time of the process, which can reduce flexibility and, also, the management efforts to coordinate and control the project through systems, procedures, documents, management tools, meetings, reviews and organizational structure.

There are companies that involve the suppliers according to their capabilities, (WARD; LIKER; CRISTIANO, 1995). This involvement can range from an effective participation in the innovation process to the simple execution of the project being developed. The definition of the final specification is left to the final stage of the design. At the beginning, we use specification ranges, in which only the critical specifications are initially frozen. This practice restricts the number of project changes at the supplier, which is thus enabled to work with them on a continuous quality and cost improvement. According to these authors, it must be stressed that such practices involve only highly qualified suppliers.

In line with Olson et al. (2001), communication and, consequently, cooperation among the areas in the NPD process - that involves $\mathrm{P} \& \mathrm{D}$ and Marketing, and $\mathrm{P} \& \mathrm{D}$ and Manufacturing - make this process more complex. Hong et al. (2005) have observed that the design engineers have a growing influence among team members in their role in the NPD process, integrating team towardsa globally optimized design with multiple performance managers (e.g. time, quality, cost and delivery).

Song, Thieme and Xie (1998) observed that the high cost of integration between R\&D and manufacturing in NPD early stages can reduce performance of the NPD process. However, before the planning phase of the project starts, it is important to establish some rules and agreements between the two areas to increase NPD process efficiency. Olson et al. (2001) and Tseng and Changhwa (2006) observed that if the level of cooperation among $\mathrm{R} \& \mathrm{D}$, marketing and manufacturing increases in the final development steps, the success of the project also increases, but only for innovative projects; in the case of less innovative ones, this effect is not observed.

In this research, the resources are usually scarce and insuficient to provide dedicated teams to the NPD projects. Thus, to understand the manufacturing's role and participation at the steps of the NPD process, it is necessary to examinehow manufacturing's interactions with the otherbusiness' functions happen.

\subsubsection{DFM and TPM methodologies}

The production improvement methodologies have always recommended production involvement since the early stages of the product and project conception. The benefits of the use of the DFM methodologies are significant, as described in the Analysis Report per Keys et al. (apud YOUSSEF, 1994):

- To improve design quality;

- To reduce product development cycle from $40 \%$ to $60 \%$;

- To reduce manufacturing cost from $30 \%$ to $40 \%$; and

- To reduce maintenance and guarantee costs.

As all methodologies, this one needs to be strictly followed otherwise the inadequate use of its tools may lead to false conclusions about its results.

According to Ireland and Dale (2001), in the beginning of the 1990's, western organizations started to be interested 
in TPM (Total Preventive Maintenance), followed by Total Quality Programs (TQM). Although there are many publications about TPM, there are few empiric studies and deeper analysis of the subject.

TPM methodologywas developed by Nakajima and published in his book in 1986. It targets to eliminate big wastes in production equipment and it is comprised of 8 pillars.

Regarding product development, the TPM methodology guarantees the best performance for production equipment; it involves all pillars (maintenance, associate training and development, safety, quality and other production routines), so that new products and processes are implemented with due involvement of appropriate personnel and operational controls.

\section{Methodology}

\subsection{An Exploratory Study of Multiple Holistic Cases}

The scope of this research is qualitative, based on the study of multiple cases in which professionals from three tangible consumer goods companies were interviewed. This research adopted a holistic approach as each case comprises the entire company and not just subunits. The study followed Yin (2003). The interviews focused on production, R\&D and marketing engineers, scientists, managers and directors, depending upon availabilityand pertinence in each company.

This is also an exploratory research with focus on a general view of the subjectunder investigated, that is, the participation of manufacturing in the NPD process, through the immersion of the researcher in a context of simple projects in a multiproject environment. It also contributes to focus on questions and identify human and other data sources (ALVES, 1991).

Considering the cases selection relevance for building theory from cases studies, we emphasize the process of selecting the suitable cases. We understand that the chosen companies are good representative organizations, for several reasons. First, companies with Brazilian or foreign capital, producing tangible consumer goods and located in the Brazilian territory and with a portfolio of simple products, with short execution times. Second, products with high capacity shared among productive process. Third, companies from different economic sectors; a heterogeneous sample of diverse business segments enables the analysis of similar administrative models, regardless of the product produced. And last, companies with simultaneous multiproject portfolio, which implement these projects and have R\&D and Marketing departments. Even in case of co-manufacturing some projects, this is not significant for the total portfolio.

The three chosen companies are large and very competitive in their business segment: a Brazilian shoe manufacturer focused on sport shoes; a multinational candy company with focus on the chocolate segment; and a multinational cosmetic company with a wide variety of products in their portfolio. We believe that these cases are typical cases since it stands for a number of cases in which a wider phenomenon occurs (GERRING, 2002).

We have gathered data from both primary and secondary sources. The latter involved public and private data available in annual reports published by companies, industry reports, local and international business magazines as well companies websites. To obtain the primary data, we have conductedinterviews using a semi-structured questionnaire with open questions to gather information about the general characteristics of the process. Directors, managers and production and $R \& D$ engineers were interviewed and the Brazilian facilities were visited. We have carried personal meetings, telephone calls and electronic messages during the interview period.

Based on the theory studied and the objectives of the research, a Theoretical Reference Model was used for the research to guide the field research and data evaluation, composed of one matrix that correlates the main management practices of the NPD process to the analysis of the manufacturing participation in the fours steps defined in the NPD process. The practices studied were aligned in four groups: (i) Project Portfolio management practices, (ii) Organizational practices, (iii) Planning and Control practices and (iv) Process Optimization practices (DFM, TPM or other). This reference model is presented in the next topic of the article.

\section{Research and data analysis}

Our collected data and results are summarized in Table 2, at the end. Bellow follows a discussion of these findings in the four categories just mentioned in our reference model.

\subsection{Project portfolio management practices}

Our research leaded to the conclusion that in the derivative projects, either incremental or topological - which are the majority in our companies' portfolios - the quality and development terms are not jeopardized if manufacturing does not take part in the product conception phase. The manufacturing's main role in these initial stages is restricted to checking if the project is derivative or not, in order to confirm whether the specification will bring major impacts to the productive process.

Although authors like Song, Thieme and Xie (1998), Olson et al. (2001), Bajaj, Kelkre and Sirinvasan (2004), Tseng and Changhwa (2006) have agreed that manufacturing participation in the early steps of NPD process is unnecessary, they do not make it clear for which type of projects this participation is appropriate.

If we analyze the project portfolio and product launching in one year, we can observe that, in the candy company, in 
Table 2. Main manufacturing participation practices in the NPD process.

\begin{tabular}{|c|c|c|c|c|}
\hline \begin{tabular}{|c|} 
Manufacturing \\
participation/ NPD \\
steps \\
\end{tabular} & $\begin{array}{c}\text { Project portfolio } \\
\text { management practices }\end{array}$ & $\begin{array}{c}\text { Organizational practices } \\
\text { (NPD process performance) }\end{array}$ & $\begin{array}{c}\text { Planning and control } \\
\text { practices }\end{array}$ & $\begin{array}{c}\text { Process optimization } \\
\text { practices (DFM and } \\
\text { TPM) } \\
\end{array}$ \\
\hline 1-Concept & $\begin{array}{l}\text { - Most of the project } \\
\text { portfolio are incremental } \\
\text { or topological with little } \\
\text { or no manufacturing } \\
\text { participation } \\
\text {-High expected sales } \\
\text { product subgroup for the } \\
\text { year are called super hits } \\
\text { for cosmetics, with proper } \\
\text { priorization process }\end{array}$ & $\begin{array}{l}\text { - Marketing area has the } \\
\text { responsibility to coordinate the } \\
\text { NPD process in all companies, } \\
\text { although P\&D acts as a link } \\
\text { among the areas involved in } \\
\text { the process }\end{array}$ & $\begin{array}{l}\text { - Annual project portofolio } \\
\text { meeting with participation of } \\
\text { all areas is conducted, with } \\
\text { periodic review during the } \\
\text { year, for all companies } \\
\text { - For global company } \\
\text { manufacturing participation } \\
\text { is less intense, due to lack of } \\
\text { resources dedicated to it, eg. } \\
\text { cosmetic company }\end{array}$ & $\begin{array}{l}\text { - Utilization of TPM(Total } \\
\text { Preventive Maintenance) } \\
\text { Methodology organize } \\
\text { the process better for } \\
\text { candy company. Cosmetic } \\
\text { company started to } \\
\text { implement some pillars } \\
\text { of the methodology }\end{array}$ \\
\hline $\begin{array}{l}\text { 2-Product and process } \\
\text { planning }\end{array}$ & $\begin{array}{l}\text { - Periodic meetings to } \\
\text { review Project portfolio } \\
\text { priorization for all } \\
\text { companies, mainly } \\
\text { cosmetic one } \\
\text { - Utilization of Gates to } \\
\text { review and reorient NPD } \\
\text { projects, consolidate } \\
\text { practice, mainly cosmetic } \\
\text { and shoe company due to } \\
\text { high number of items }\end{array}$ & $\begin{array}{l}\text { - The co-localization of NPD } \\
\text { project teams in the literature } \\
\text { is substituted by physical co- } \\
\text { located departments: P\&D, } \\
\text { Marketing and Manufacturing } \\
\text { to enhance integration and } \\
\text { the decision process of NDP } \\
\text { process, mainly candy and } \\
\text { shoes company as cosmetic is } \\
\text { a global company }\end{array}$ & $\begin{array}{l}\text { - Development of an } \\
\text { information "package" to } \\
\text { transfer projects from P\&D } \\
\text { to manufacturing - good } \\
\text { practice developed by shoe } \\
\text { company. }\end{array}$ & $\begin{array}{l}\text { - Experienced personnel } \\
\text { gatekeepers helps projects } \\
\text { conduction for all } \\
\text { companies (diferent areas) } \\
\text { - Records of lessons } \\
\text { learned from other } \\
\text { projects supports project } \\
\text { development- candy } \\
\text { company } \\
\text { - CAD is a tool used } \\
\text { to develop project } \\
\text { prototypes - shoe } \\
\text { company }\end{array}$ \\
\hline $\begin{array}{l}\text { 3-Product and process } \\
\text { implementation }\end{array}$ & $\begin{array}{l}\text { - Analysis of project } \\
\text { G O / K i l l b e f o r e } \\
\text { implementation, with } \\
\text { possible discontinuation of } \\
\text { the project before or during } \\
\text { implementation. Critical } \\
\text { process for senior people } \\
\text { participation - global } \\
\text { cosmetic company }\end{array}$ & $\begin{array}{l}\text { - Project is conducted through } \\
\text { frequent multitask meetings to } \\
\text { follow up project activities for } \\
\text { all companies } \\
\text { - Job rotation from } \\
\text { manufacturing to P\&D is a } \\
\text { practice to help the process, } \\
\text { observed mainly in shoe } \\
\text { company }\end{array}$ & $\begin{array}{l}\text { - Projects managed in } \\
\text { a sequential way with } \\
\text { burocratic controlsfor all } \\
\text { companies } \\
\text { - Annual performance } \\
\text { targets shared among key } \\
\text { participants or areas for all } \\
\text { companies } \\
\text { - Records of lessons learned- } \\
\text { good practice candy company }\end{array}$ & $\begin{array}{l}\text { - C AD/CAM fast } \\
\text { prototypes of final product } \\
\text { and process } \\
\text { uses same production } \\
\text { machines to define } \\
\text { process parameters - shoe } \\
\text { company }\end{array}$ \\
\hline 4-Commercialization & $\begin{array}{l}\text { - Products follow up } \\
\text { after launching, with } \\
\text { possible adjustments or } \\
\text { improvements, mainly } \\
\text { candy company }\end{array}$ & $\begin{array}{l}\text { - More mature and disciplined } \\
\text { teams improved NPD process } \\
\text { with less reworking after } \\
\text { product launching - shoe } \\
\text { company }\end{array}$ & $\begin{array}{l}\text { - Pre prepared project } \\
\text { packages help reduces } \\
\text { firefighting in shoes company }\end{array}$ & $\begin{array}{l}\text { - TPM Methodology } \\
\text { associated helps eliminate } \\
\text { errors in production mode- } \\
\text { candy company }\end{array}$ \\
\hline
\end{tabular}

Brazil, there are nearly 500 projects and 100 new launchings yearly. As far as the cosmetic company is concerned, there are approximately 3000 projects in the global portfolio with 500 new launchings in Brazil, and 4000 project portfolio with 3000 (1000 of sports shoes - focus of the research) yearly new launchings in Brazil that refer to the shoes company. In the three companies, at least $70 \%$ of new product launchings are incremental or topological derivatives, with some platform products and some breakthroughs. The breakthroughs are less frequent, usually on an annual or bi annual basis, both in the cosmetics and shoes companies, as they have a R\&D for NPD structure apart from the technology $R \& D$, this last one being responsible for the new materials development.
In these companies, the participation of personnel from the different areas involved in the NPD process, to analyze and filter projectsat the gates and to evaluate project continuity or interruption is critical to prevent time waste in their multiproject environments. For all companies, it is a challenge to put the people with the right hierarquic level in the proper committees.

The practice of using gatesis a methodology strongly used by companies according to Cooper, Scott and Kleinschmidt (2002), and according to the author this practice helps improve product profitability but requires senior people participation. However, as per Cooper's research (1994), it is a fluid and flexible process, with no rigidity in their different stages. Besides the analysis of 
each project, it is possible to evaluate the project portfolio as a whole and focus the main projects. The author also reinforces that the go/kill gates could be impacted by the number of projects examined andthe lack of senior resources required to participate in all these project decisions. In this research the senior engajemet was more difficult in the global cosmetic company.

An example of a portfolio focus is the NPD project group named super hits, a practice used in the cosmetic organization to highlight the main projects of the year. This group (local, regional and global) gathers the main projects of the company during the year, the ones responsible for most of the forecasted annual sales. It enables management to closely follow-up the main projects of the company, and it also sheds more light on the participation of the different areas, including manufacturing.

\subsection{Organizational practices}

The industrial area is dominant in the candy and shoes companies when compared with other areas in the business. Such dominance is similar to the one found by Leonard-Barton (1992) in a study performed on a chemical industry in which resources are prioritized for this area in detriment to the others. However, in our cosmetic company, witha background history based on a new sales system, the direct sales system, the dominant area of the company is sales.

One aspect enlightening the difference of influence of a dominant area is that of communication in the candy company, or in the shoes company, as it is driven by the language used in the industrial area, whereas, in the cosmetic company, marketing and manufacturing speak different languages. This situation can raise communication barriers and promote conflictabout projects and studies among the areas (COOPER; SCOTT; KLEINSCHMIDT, 2004; GRIFFIN; HAUSER, 1996; OLSON et al., 2001).

$R \& D$ is the link among the areas involved in the NPD process. This R\&D link role was also reinforced by Fredericks (2005) and Bajaj, Kelkre and Sirinvasan (2004). An additional contribution to the literature is the communication facilitator role of R\&D to translate the communication language among the areas, as communication barriers are highlighted in literature (COOPER; SCOTT; KLEINSCHMIDT, 2004; GRIFFIN; HAUSER, 1996; OLSON et al., 2001). This translation need was observed in the cosmetic industry, in which manufacturing and marketing use different language terminologies for the product groups.

In our three studied companies, the co-locationof the project teams is partially replaced by $R \& D$ and Marketing areas and/or factory co-location. In the candy company, $\mathrm{R} \& \mathrm{D}$ and factory are co-located. In the cosmetics company, $\mathrm{R} \& \mathrm{D}$, Marketing and some factories' global human resourcesare co-located. So, this seems an additional contribution to the literature as it deals with multiproject and simple product environments.

In the shoes company, according to interviews and field visit, the manufacturing role and participation in the NPD projects officially begins with the product and process development. However, considering manufacturing significant knowledge and level of influence on other areas, it is said that manufacturing participation in the NPD process happens at all stages, since the generation of ideas. These companies heavily count on experienced managers, considered as the company's gatekeepers (ALLEN, 1997; ETTLIE; EINSENBACH, 2007; KATZ; TUSHMAN, 1981).

For the breakthrough or plataform product developments, which reach higher finantial benefits, the participation of the areas and of the highest hierarquic levels of the company seems to be a regular practice, as most of annual sales come from new products.

No special recognition for NPD teams was a practice in any company studied.

\subsection{Planning and control practices}

In the three companies studied, there is a big annual brainstorming meeting involving all areas, during which the first list of project ideas is created and then appropriate filters/gates will follow for project development and implementation.

It was also observed that the project list is reviewed at least four times during the year, in smaller meetings, depending upon the business dynamics, mainly in the cosmetics and shoes companies.

The brainstorming practice is more recent and formal in the candy company. The practice also exists in the cosmetic company, with scarce global functional manufacturing representatives in the $R \& D$ and Marketing meetings. As there is no participation of manufacturing, or more specifically of factory associates, the organization expects that the R\&D process personnel be the link to the factories. This is a difficult task due the low number of R\&D process people and the high number of global products, with more than 10 factories globally with different production technologies.

The NPD project administration is performed sequentially, that is, with burocratic control and by means of alliances among personnel from the different departments, according Olson, Walker and Rueker (1995). As previously mentioned, the sequential way to control the projects is not rigid.

Nascimento (2002) described project portfolio management in three different modes, each revealed in a different company. The author examined a cosmetic company with a project portfolio composed of many small projects, each without dedicated human resources, with a relatively short time frame, and representing a small part of the total innovation investment. This portfolio was managed 
in a decentralized way, very differently from an aircraft company, with more complex projects, such as aircrafts. On this company, there was a big program that has been their main investmentfor five to ten years. This program has had the top management direct involvement in its approval and development process, which therefore reveals a centralized project portfolio management. Between these two portfolio management extremes, there was a company with a project portfolio composed of a few programs, platforms and their derivatives, that enable a more participative management, in which the project leaders answer to program managers with a seat in the executive board, creating an integrative management of programs and functions. This research empirically supports the type of decentralized NPD project management found in the researched companies.

A fact observed in the candy company is the existence of a lessons-learned book for each project and the sharing of operational and financial goals among the associates, which is part of the daily NPD project management routine in the company. This work practice is related to the TPM methodology implemented, duly audited and certificated.

Another practice used in the three studied companies is monitoring the schedule of activities, in order to follow the project evolution. This follow-up is made of people from different areas, especially R\&D. All companies in question present different types of activity schedules, due to the critical path in each particular project. This critical path can be originated by the packaging mold development timeframe, material importation lead time, machine purchase and delivery terms, etc.

Among the planning and control practices, a "previously prepared project package" was observed in the shoes and cosmetics companies. In the case of the shoes company, this "preset project package" is dedicated to Brazil; in the cosmetics company, the development of products for many different markets enables these products be used as finished projects by other unities of the company.

This practice makes easier the developing project management, besides ensuring quality in its implementation. In case any project is eliminated (for commercial or technical reasons) before or during the commercialization step, a finished project can be used without necessarily accelerating the development of the on-going projects. To accelerate the NPD process time may jeopardize the results of the project.

This approach of preset projects, can reduce the fire fighting situation, as highlighted by Repenning (2001) in his study, as NPD process execution and resource planning is less affected by this situation.

\subsection{Process optimization practices (DFM and TPM)}

The TPM methodology is used in the three companies; however, the candy company is the only one to have the eight pillars duly implemented with appropriate audits and certifications. Among these pillars, there is the initial control pillar, which involves the different areas of the NPD process, from the generation of ideas until the product commercialization. Particularly in the manufacturing case, the participation in the NPD process is easier, with roles and responsibilities defined according to this methodology, which involves quality, safety, training, maintenance, production and engineering in the operational standard definitions.

For the shoes company, besides four TPM pillars, the utilization of CAD/CAM systems for product development, quick prototype and project implementation in production enables the creation of the project transfer "package" from R\&D to the factories, prepared together with the industrial area. This "package" is composed of: equipment programming (CAM) - the same of the pilot factory - machine tools, production DVD for each process step, specifications with pictures of all steps of the process as well as of the finished product, personnel and equipment estimation for each product, besides the samples and material specifications to be used in the product manufacturing.

This package enables the product transference from $R \& D$ to production in any production facility due to the utilization of equipment similar to the ones used in development and production. However, this is not feasible in the candy and cosmetic companies, due to the scale difference between pilot and full production.

The DFM methodology - as a group of rules that optimizes the manufacturing process, used by designers and by process and product development teams, as described by Bancrof (1988) and Yuossef (1994) - was not formally found in the three companies studied. However, it is a tacit knowledge among the people who participate in the development process.

The three companies were compared in Table 2, using the formerly defined NPD steps and the participation types. Some formalized and non-formalized practices were presented in an abreviated form.

\section{Final remarks}

Our three companies have manufacturing following all stages of the product life, depending on each product'sshare in the total production volume. Manufacturing continues to inprove processes/production equipment, focusing on operational efficiency and cost reduction. This process improvement happens regardless of the project being part or not of the new product/process project portfolio.

Manufacturing participation is significant at the initial steps of the NPD process, as factory preparation can be critical to the product launching schedule, considering that most products are launched in an one-year time frame. 
An important finding was that the R\&D regularly reported to the Marketing organization. Maybe this $\mathrm{R} \& \mathrm{D}$ reporting arrangememt is a common practice in the consumer goods companies with a multiproject environment in which the topological derivative innovation is dominant. This sugestion could be better explored in future research.

It is significant to mention the small manufacturing'srole in the NPD project portfolio management at the studied companies. Manufacturing is mostly involved in the projects development and production steps, which are normally very extensive in a multiproject and simple product environment.

As it is not possible to have dedicated and co-located people to each project, the solution of co-locating entire departments facilitates communication, as well as the decision making process among NPD process professionals.

The new products frequent launching creates a dynamic and continuous process environment. Mistaken information flow and decision making may lead to errors in the project's final stage. This may result in conflict among the areas involved in the NPD process and in problem solving, increasing the challenges to the projects' transition from the pilot to the industrial scale. Other aspect that might create more conflict is the lack of methodologies to manage the NPDactivities. This topicrequiresfurther and deeper assessment in future research.

\section{References}

ANCANO, D.; CALDWELL, D. Improving the performance of new products teams. Research-Technology Management, v. 50, n. 5, p. 37-43(7), 2007.

ADLER, P. Interdepartamental Interdependence and Coordination: The Case of theDesign Manufacturing Interface. Organization Science, v. 6, n. 2, p. 147-167, 1995.

ALLEN, T. Communications, technology transfer, and the role of technical gatekeeper. R\&D Management, v. 1, p. $14-21,1997$

ALVES, J. O planejamento de pesquisas qualitativas em educação. Caderno de Pesquisa, v. 77, p. 53-61, 1991.

ASH, R.; SMITH-DANIELS, D. The effects of Learning, Forgetting, and relearning on Decision Rule Performance in Multiproject Schedulling. Decision Science, v. 30, n. 1, p. 47-82, 1999.

BAJAJ, A.; KELKRE, S.; SIRINVASAN, K. Managing NPD: cost and schedule performance in design and manufacturing. Management Science, v. 50, n. 4, p. 527-536, 2004. PMid:3769170.

BANCROFT, C. Overlooked Aspects of Design for Manufacturability. IEE Circuits and Devices Magazine, v. 4, n. 6, p. 15-10, 1988. http://dx.doi.org/10.1109/101.9571

BROWN, S.; EISENHARDT, K. Product development: past research, present findings, and future directions.
The Academy of Management Review, v. 20, n. 2, p. 343-378, 1995.

CALANTONE, R.; DRÖGE, C.; VICKERY, S. Investigating the manufacturing- marketing interface in new product development: does context affect the strengh of relations. Journal of Operations Management, v. 20, n 3, p. 273-287, June 2002. http://dx.doi.org/10.1016/S02726963(02)00009-8

CLARK, K.; FUJIMOTO, T. Product development performance. Boston: Harvard Business School Press, 1991.

CLARK, K.; WHEELWRIGHT, S. Managing new product and process development. Boston: Harvard Business School Press, 1993.

COOPER, R.; SCOTT, E.; KLEINSCHMIDT, E. Best NPD Practices - I. Research Technology Management, v. 47, n. 1, p. 31, 2004.

COOPER, R.; SCOTT, E.; KLEINSCHMIDT, E. Best NPD Practices -II. Research Technology Management, v. 47, n. 3, p. 50, 2004.

COOPER, R.; SCOTT, E.; KLEINSCHMIDT, E. Best NPD Practices -III. Research Technology Management, v. 47, n. 6, p. 43, 2004.

COOPER, R.; SCOTT, E.; KLEINSCHMIDT, E. Optimizing the stage-gate process: What best-practice companies do -II. Research Technology Management, v. 45, n. 2, p. 21-7, 2002. PMid:15487845.

COOPER, R. Perpective: Thrid- Generation New Product Processes. Journal of Product Innovation Mangament, v. 11, p. 3-14, 1994.

ETTLIE, J.; ELSENBACH, J. The changing role of R\&D gatekeepers. Research Technology Management, v. 50, n. 5, p. 59-66, 2007.

FREDERICKS, E. Cross-functional involvement in new product development. Aresourcedependency and human capital perspective. Qualitative Market Research. An International Journal, v. 8, n. 3, p. 327-34, 2005.

GERRING, J. Case study research: principles and practices. New York: Cambridge University Press, 2002. PMid: 15487845.

GERWIN, D.; BARROWMAN, N. An Evaluation of Research on Integrated Product Development. Management Science, v. 48, n. 7, p. 938-953, July 2002. http://dx.doi.org/10.1287/ mnsc.48.7.938.2818

GRIFFIN, A.; ANSCHETZ, N.; CASTELLION, G. The PDMA Handbook of New Products Development. Canada: John Wiley \& Sons, Inc., 1996. PMid:15487845.

GRIFFIN, A.; HAUSER, J. Integrating R\&D and Marketing: a review and analysis of the literature. Journal of Product 
Innovation Management, v. 13, n. 3, p. 191-215, 1996. PMid:15487845.

GUPTA, S. Speeding Development. Appliance Design, v. 53, p. 30, 2005.

HENKE, W. et al. Cross-Functional Teams: Good Concept, Poor Implementation! Journal of Product Innovation Management, v. 1, p. 216 -229, 1993.

HONG, P. et al. Role Change of design engineers in product development. Journal of Operations Management, v. 24, p. 63-79, 2005.

IRELAND, F.; DALE, B. A study of total productive maintenance implementation. Journal of Quality in Maintenance Engineering, v. 7, n. 3, p. 183, 2001.

KATZ, R.; TUSHMAN, M. An Investigation into the managerial roles and career paths of gatekeepers and project supervisors in a major R\&D facility. R\&D Management, v. 11, n. 3, 1981.

LEONARD-BARTON, D. Core Capabilities and core rigidities: A paradox in managing new product development. Strategic Management Journal, v. 13, n. S1, p. 111-125, 1992.

MATAR, F.; SANTOS, D. Gerência de Produtos: Como tornar seu produto um sucesso. 2. ed. São Paulo: Editora Atlas, 2003. PMid:15487845.

NASCIMENTO, P. Embraer, Natura e Daimler Chrysler do Brasil: Três modos de gerir o desenvolvimento de produtos. In: SEMINÁRIOS EM ADMINISTRAÇÃO - SEMEAD, 2002, São Paulo. Anais... São Paulo: Universidade de São Paulo, 2002. PMid:15487845.

OLSON, E.; WALKER, O.; RUEKER, R. Organizing for effective new product development: the moderating role of product innovativeness. Jornal of Marketing, v. 59, n. 1, p. 48-62, 1995. PMid:15487845.

OLSON,E. et al. Patterns of cooperation during new product development among marketing, operations and R\&D: Implications for project performance.The
Journal of Product Innovation, v. 18, p. 258-27, 2001. PMid:15487845.

RAMA, Y.; HERBIG, P. Global markets and the new product development process. The Journal of Product and Brand Management, v. 5, n. 6, p. 38, 1996.

REID, R.; SANDERS, N. Gestão de Operações. Rio de Janeiro: LTC, 2005.

REPENNING, N. Understanding fire fighting in new product development. The Journal of Product Innovation Management, v. 18, n. 5, p. 285-300, 2001.

SANDERSON, S.; UZUMERI, M. Managing product families: The case of Sony Walkman. Research Policy, v. 24, n. 5, p. 761-782, 1995.

SONG, X.; THIEME, R.; XIE, J. The Impact of CrossFunctional Joint Involvement across Product Development Stages: An Exploratory Study. Journal of Product Innovation Management, v. 15, n. 4, p. 289-303, 1998.

TRITLE, G.; SCRIVEN, E.; FUSFELD, A. Resolving Uncertainty in R\&D Portofolios. Research Technology Management, v. 43, n. 6, p. 47-55, 2000.

TSENG, Y.; CHANGHWA, Y. Examining the Relationship between the Design-Manufacturing Cooperation and New Product Development Time Performance: The Moderating Role of Technological Innovativeness. The Journal of American Academy of Business, v. 9, n. 1, 2006.

YIN, R. Case Study Research: Design and Methods. 2nd ed. Sage Publications, Inc., 2003.

YOUSSEF, M. Design for manufacturability and time-tomarket (part 1). International Journal of Operations \& Production Management, v. 14, n. 12, p. 6, 1994.

WARD, A.; LIKER, J.; CRISTIANO, J. The second toyota paradox: how delaying decisions can make better cars faster. Sloan Management Review, v. 36, n. 3, p. 43-61, 1995. 